\title{
EFFECTS OF SEVERAL ANTHRACYCLINE ANTITUMOR ANTIBIOTICS ON THE TRANSCRIPTIONAL ACTIVITY OF ISOLATED NUCLEOLI
}

\author{
Virgil H. DuVernay and Stanley T. Crooke \\ Bristol-Baylor Laboratories, Department of Pharmacology, Baylor College of Medicine, \\ Houston, Texas 77030, U.S.A. \\ Bristol Laboratories, Syracuse, New York 13201, U.S.A.
}

(Received for publication January 11, 1980)

\begin{abstract}
The class II anthracycline antitumor antibiotics musettamycin, rudolfomycin, aclacinomycin and marcellomycin, which were shown in earlier studies to preferentially inhibit the synthesis of nucleolar RNA in intact tumor cells, were studied in an isolated nucleolar transcriptional assay. Their effects were compared with those of the nucleolar non-selective anthracyclines adriamycin, carminomycin and pyrromycin, as well as with the 10-descarbomethoxyanalogs of marcellomycin and rudolfomycin. The isolated nucleolar transcriptional assay was found to have linear activity for 30 minutes at $30^{\circ} \mathrm{C}$. At increasing concentrations of $\alpha$ amanatin up to $200 \mu \mathrm{g} / \mathrm{ml}$, the maximum degree of inhibition of transcriptional activity was found to be $6 \sim 7 \%$. The ranking of nucleolar RNA synthesis inhibitory potencies of the class I and II anthracyclines and the 10-descarbomethoxy-analogs obtained previously in intact cells was reproduced in the isolated nucleoli assay system described here. Thus, evidence for the use of this assay as a screen for nucleolar active antitumor agents is presented.
\end{abstract}

A biochemical method employing a cell-free homogenate to screen for antitumor antibiotics was previously reported by NITTA and co-workers ${ }^{1)}$ and was used successfully to detect phenomycin, an inhibitor of protein synthesis ${ }^{2)}$. Recently, SAKANO and co-workers ${ }^{3)}$ employed a purified mouse RNA polymerase assay to detect nucleic acid active antitumor agents. However, no studies on the use of isolated nuclei or nucleoli as a screen for antitumor agents with specific mechanisms of action have been reported.

Anthracyclines represent a major class of antitumor antibiotics and include the analogs adriamy$\operatorname{cin}^{4,5)}$ (ADM), carminomycin ${ }^{4,5,6)}(\mathrm{CMM})$, aclacinomycin ${ }^{4,5,7,8)}$ (ACM) and marcellomycin ${ }^{5,8)}$ (MCM). The results of extensive studies by many groups have demonstrated that these compounds can exert a variety of biochemical effects on cells, including DNA template interactions and the resultant perturbation of normal nucleic acid synthesis and metabolism ${ }^{4,5,8,7,8,9)}$. This latter effect is thought to play a significant role in the antitumor action of the anthracyclines. We have previously demonstrated that anthracyclines can be divided into two classes based upon their selectivity for the inhibition of nucleolar pre-ribosomal RNA (No-RNA) synthesis in intact mammalian tumor cells grown in culture ${ }^{5,9}$. This assay compared the results of two separate determinations to evaluate the nucleolar selectivity of a drug by taking the ratio of the $\mathrm{IC}_{50}$ value for DNA synthesis to the $\mathrm{IC}_{50}$ value for No-RNA synthesis ${ }^{5,9}$. . In addition to detecting the nucleolar-specific actions of drugs, the assay was both sensitive and reproducible. However, the methods employed in these studies do not allow rapid screening of compounds because the procedures used are time and compound consuming, Thus, the assay proved impractical

Abbreviations: No-RNA, nucleolar RNA; ADM, adriamycin; ACM, aclacinomycin; PMSF, phenyl methyl sulfonyl fluoride; $\mathrm{IC}_{50}, 50 \%$ inhibitory concentration; CMM, carminomycin; MSM, musettamycin; MCM, marcellomycin; PYM, pyrromycin; RDM, rudolfomycin; D-MCM, 10-Descarbomethoxymarcellomycin; D-RDM, 10-Descarbomethoxyrudolfomycin. 
for screening large numbers of compounds, and consequently many potentially nucleolar selective agents may go undetected. Therefore, the present study was undertaken to determine whether effects on isolated nucleoli could be employed to predict for selectivity of No-RNA synthesis inhibition in vivo among the anthracyclines.

Nucleoli were isolated from NoviKoff hepatoma ascites cells as previously described by BALLAL and co-workers ${ }^{10)}$. RNA synthesis in isolated nucleoli was assayed according to previously reported methods $^{10,11,12)}$.

Fig. 1 shows the structures of the anthracyclines which were studied. The nucleolar selectivity of these agents has been previously reported ${ }^{5,9)}$, employing intact mammalian tumor cells. Included are the nucleolar selective (class II) anthracyclines-MCM, ACM, musettamycin (MSM) and rudolfomycin (RDM)- and the nucleolar non-selective (class I) anthracyclines- ADM, CMM and pyrromycin (PYM), as well as the semisynthetic class II analogs, 10-descarbomethoxymarcellomycin (D-MCM) and 10descarbomethoxyrudolfomycin (D-RDM).

Fig. 1. Structures of the class I and class II anthracyclines and the descarbomethoxy-analogs of marcellomycin and rudolfomycin.

Class I Anthracyclines

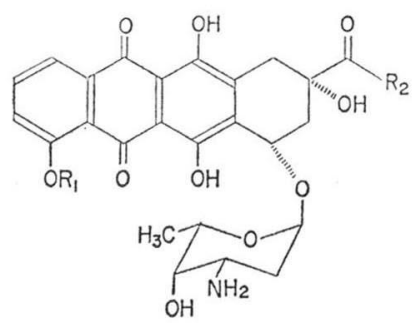

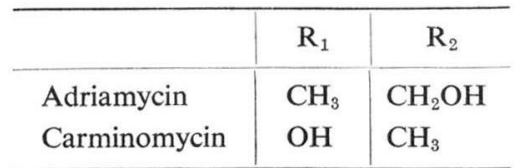

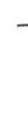

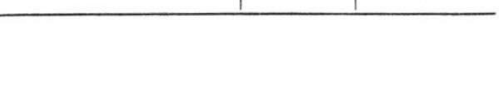

Class II Anthracyclines

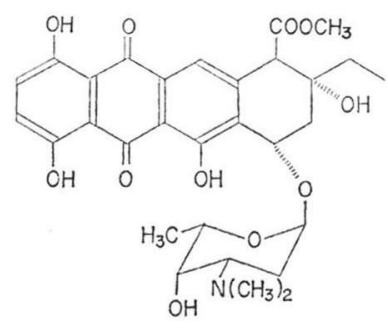

Pyrromycin

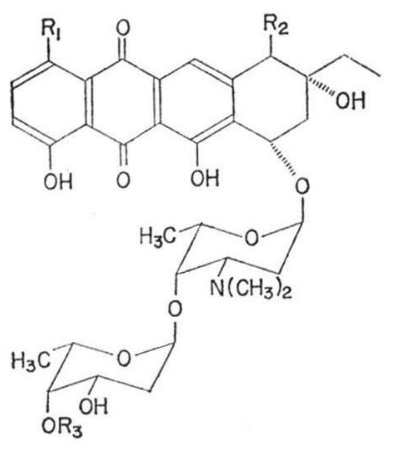<smiles>CC1CCC(C)OC(C)C1</smiles><smiles>CC1CC(O)C(O)CC(C)O1</smiles>
2-Deoxyfucose

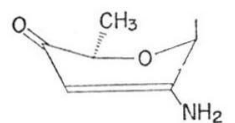

Rednosamine

\begin{tabular}{|c|c|c|c|}
\hline Anthracycline & $\mathrm{R}_{1}$ & $\mathrm{R}_{2}$ & $\mathrm{R}_{3}$ \\
\hline Musettamycin & $\mathrm{OH}$ & $\mathrm{COOCH}_{3}$ & $\mathrm{H}$ \\
\hline Rudolfomycin & $\mathrm{OH}$ & $\mathrm{COOCH}_{3}$ & Rednosamine \\
\hline Aclacinomycin & $\mathrm{H}$ & $\mathrm{COOCH}_{3}$ & Cinerulose \\
\hline Marcellomycin & $\mathrm{OH}$ & $\mathrm{COOCH}_{3}$ & 2-Deoxyfucose \\
\hline $\begin{array}{l}\text { Descarbomethoxy- } \\
\text { marcellomycin }\end{array}$ & $\mathrm{OH}$ & $\mathrm{H}$ & 2-Deoxyfucose \\
\hline $\begin{array}{l}\text { Descarbomethoxy- } \\
\text { rudolfomycin }\end{array}$ & $\mathrm{OH}$ & $\mathrm{H}$ & Rednosamine \\
\hline
\end{tabular}

Fig. 2 shows the kinetics of the incorporation of ${ }^{3} \mathrm{H}$-UMP into RNA transcripts in isolated nucleoli. There was an increase in the incorporation of ${ }^{3} \mathrm{H}$-UMP during the first $20 \sim 30$ minutes of the incubation followed by a slight decrease and eventual plateau. The reaction time selected for further experiments was 30 minutes.

WEINMAN and ROEDER ${ }^{13)}$ have shown that the $\mathrm{IC}_{50}$ values for $\alpha$-amanatin for RNA polymerases I, II and III were $500 \mu \mathrm{g} / \mathrm{ml}$, approximately $0.02 \mu \mathrm{g} / \mathrm{ml}$ and approximately $20 \mu \mathrm{g} / \mathrm{ml}$, respectively. Since 
Fig. 2. Time course of the incorporation of ${ }^{3} \mathrm{H}-$ UMP into in vitro RNA transcripts by isolated nucleoli.

Procedures used are as indicated in "Experimental" section. Aliquots of $0.05 \mathrm{ml}$ were removed at appropriate time points and processed as earlier reported $^{12)}$. Curve shown represents the results of 2 separate experiments.

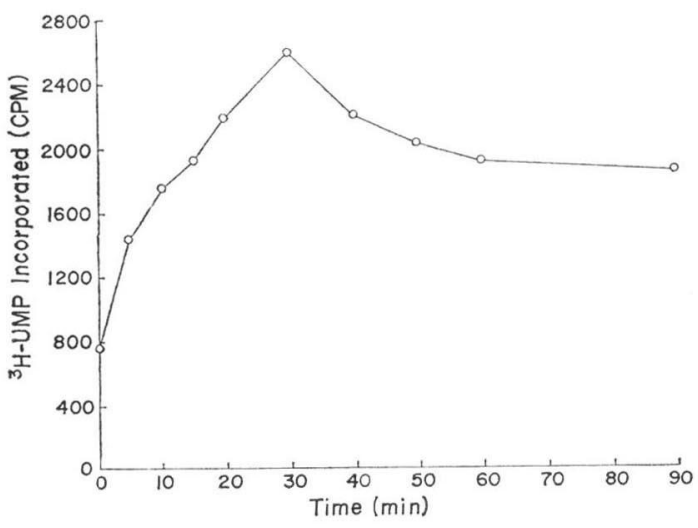

Table 1. $50 \%$ Inhibitory concentrations of several anthracyclines on the transcriptional activity of isolated nucleoli.

Nucleoli were isolated and transcriptional activity assayed as described in "Experimental" section. The results of drug concentration studies were analysed by probit analysis ${ }^{5,9,15)}$ similar to Fig. 3, and $\mathrm{IC}_{50}$ values estimated by constructing best fit lines. Values were derived from the results of a minimum of 2 separate experiments.

\begin{tabular}{l|r}
\hline \multicolumn{1}{c|}{ Anthracycline } & $\mathrm{IC}_{50}$ Values $(\mu \mathrm{M})$ \\
\hline Adriamycin & 61.8 \\
Carminomycin & 314.9 \\
Pyrromycin & 152.2 \\
Musettamycin & 8.5 \\
Rudolfomycin & 7.5 \\
Aclacinomycin & 10.9 \\
Marcellomycin & 5.6 \\
Descarbomethoxy- & 64.0 \\
marcellomycin & 86.5 \\
Descarbomethoxy- & \\
\hline rudolfomycin &
\end{tabular}

RNA polymerase $\mathrm{I}$ is localized within the nucleolus ${ }^{14)}$, the degree of inhibition of in vitro transcriptional activity by $\alpha$-amanatin estimates the level of purity of the nucleolar preparation. Treatment of the isolated nucleoli with increasing concentrations of $\alpha$-amanatin, of up to $200 \mu \mathrm{g} / \mathrm{ml}$, resulted in a maximal inhibition of transcriptional activity of approximately $7 \%$ at the highest concentration (data not shown). Thus, minimal levels of contamination by polymerases II and III are indicated.

Fig. 3 shows the probit analyses of the effects of the class I anthracyclines ADM and CMM and the class II anthracycline MSM on the transcriptional activity of isolated nucleoli. Probit analysis was chosen because it linearizes a dose-response curve and therefore allows for an accurate estimation of the $50 \%$ inhibitiony concentrations ( $\mathrm{IC}_{50}$ values). Thus, least squares analyses were applied to these curves and $\mathrm{IC}_{50}$ values estimated ${ }^{5,9,15}$. Table 1 lists the $\mathrm{IC}_{50}$ values for No-RNA synthesis in isolated nucleoli of the 9 anthracyclines studied. In addition, the effect of actinomycin D was examined, and an $\mathrm{IC}_{50}$ value of $0.98 \mu \mathrm{M}$ was obtained. Based on the relative potencies for the inhibition of transcriptional activities in vitro, the current results are in good correlation with the previous studies using intact cells ${ }^{5,9}$ ) , even though absolute $\mathbf{I C}_{50}$ values differed between the two assay systems.

To test the validity of the in vitro assay, the relative nucleolar selectivities of the drugs were compared for the two assays. In the present study, using the $\mathrm{IC}_{50}$ values for DNA synthesis previously determined for each of the nine anthracyclines studied ${ }^{5,9)}$ and the $\mathrm{IC}_{50}$ values for No-RNA synthesis in isolated nucleoli (Table 1), the nucleolar selectivities of the anthracyclines were determined as indicated in Table 2. Although the absolute values of the ratios differ significantly from those previously determined in whole cells for each anthracycline ${ }^{5,9)}$, the three groups of anthracyclines can readily be distinguished and are equivalent by both methods. Class I anthracyclines, ADM, CMM and PYM, had the lowest ratios and the class II anthracyclines, MSM, MCM, ACM and RDM, had significantly higher values, while the descarbomethoxy-analogs of RDM and MCM had intermediate ratios. Thus, the utility of the isolated nucleoli system screening assay to detect nucleolar selective anthracyclines is demonstrated. 
Fig. 3. Probit analysis of the effects of adriamycin, carminomycin, and musettamycin on in vitro nucleolar RNA synthesis.

These results are typical of those of other anthracyclines. Procedures used were as indicated in "Experimental" section. The data for drug treated samples were compared to those of the control, and the percentage inhibition of incorporation of ${ }^{3} \mathrm{H}-\mathrm{UMP}$ into in vitro No-RNA transcripts was determined. Linear regression analyses were applied to the resulting curves, and coefficients of correlation greater than 0.94 were obtained. The curves obtained represent the results of a minimum of 2 separate experiments.

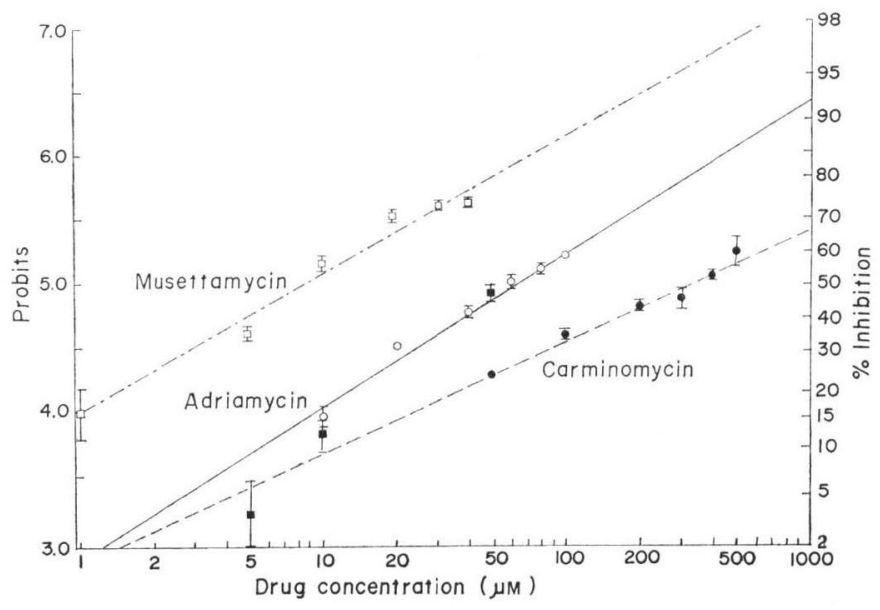

Table 2. Inhibition of nucleolar RNA synthesis relative to whole cellular DNA synthesis.

The $\mathrm{IC}_{50}$ values for in vitro No-RNA synthesis were obtained from Table 1. IC $\mathrm{I}_{50}$ values for DNA and No-RNA syntheses in intact cells, as well as the ratios of $\mathrm{IC}_{50}$ DNA: $\mathrm{IC}_{50}$ values for No-RNA were obtained from previous publications from this laboratory ${ }^{5}$.

\begin{tabular}{|c|c|c|c|c|c|}
\hline \multirow{3}{*}{ Anthracycline } & \multicolumn{2}{|c|}{ Isolated nucleoli } & \multicolumn{3}{|c|}{ Intact cells } \\
\hline & \multirow{2}{*}{ Ratio } & $\mathrm{IC}_{50} \mathrm{DNA}^{\mathrm{a}}$ & \multirow{2}{*}{$\begin{array}{c}\mathrm{IC}_{50} \mathrm{DNA}^{\mathrm{a}} \\
\text { Synthesis } \\
(\mu \mathrm{M})\end{array}$} & \multirow{2}{*}{ Ratio } & $\mathrm{IC}_{50} \mathrm{DNA}^{\mathrm{a}}$ \\
\hline & & $\mathrm{IC}_{50} \mathrm{No}^{\mathrm{R}} \mathrm{NA}^{\mathrm{b}}$ & & & $\mathrm{IC}_{50} \mathrm{No} \mathrm{RNA}^{\mathrm{a}}$ \\
\hline Adriamycin & & 0.10 & 6.1 & & 1.02 \\
\hline Carminomycin & & 0.05 & 14.7 & & 1.12 \\
\hline Pyrromycin & & 0.04 & 5.7 & & 0.93 \\
\hline Musettamycin & & 1.17 & 10.0 & 71 & 4 \\
\hline Rudolfomycin & & 9.27 & 69.7 & 2 & 10 \\
\hline Aclacinomycin & & 0.58 & 6.3 & 17 & 70 \\
\hline Marcellomycin & & 2.04 & 11.3 & 125 & \\
\hline $\begin{array}{l}\text { Descarbomethoxy- } \\
\text { marcellomycin }\end{array}$ & & 0.30 & 18.99 & & 7.42 \\
\hline $\begin{array}{l}\text { Descarbomethoxy- } \\
\text { rudolfomycin }\end{array}$ & & 0.21 & 18.37 & & 2.01 \\
\hline
\end{tabular}

a Obtained from earlier studies ${ }^{5}$.

b Obtained from Table 1 .

The $\mathrm{IC}_{50}$ values for No-RNA synthesis obtained in this study vary from 9-fold to greater than 25fold higher than values noted when intact cells were studied ${ }^{5,9)}$. The decreased No-RNA synthesis inhibitory potency of anthracyclines studied in isolated nucleoli may be accounted for on the basis of a reduction of (or absence of) reinitiation of preribosomal RNA chains in isolated nucleoli ${ }^{10,10)}$. Al- 
ternatively, cytoplasmic or other cellular factors (e.g., drug activation or modification, or drug localization) may be important in anthracycline-induced nucleolar effects. It is also possible that the nucleolar effects may be due to several actions which occur in concert in the cell, as a result of anthracycline antitumor action, and in the isolated nucleoli one or more of the processes required for maximum No-RNA synthesis inhibition is absent.

\section{Experimental}

Materials

${ }^{3}$ H-labeled UTP was obtained from Schwarz/Mann. Adriamycin (Adria-Labs, Wilmington, Del.) and the other anthracyclines were supplied by Bristol Laboratories, Syracuse, New York. Unlabeled nucleoside triphosphates and $\alpha$-amanatin were purchased from Sigma Chem. Co. Actinomycin D (Dactinomycin, Merck, Sharp \& Dohme, West Point, PA) was a generous gift of Dr. M. LANE.

\section{Methods}

\section{Isolation of Nucleoli}

Nucleoli were isolated from 6-day old NoviKOFF hepatoma ascites cells by the methods of BALLAL

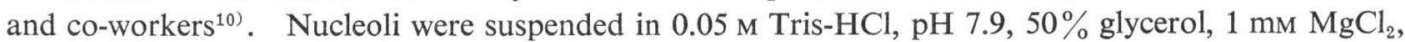
$0.05 \mathrm{~mm}$ phenylmethyl sulfonyl fluoride (PMSF), $2 \mathrm{~mm}$ dithiothreitol, $0.1 \mathrm{~mm}$ EDTA, and stored at $-80^{\circ} \mathrm{C}$

\section{RNA Synthesis in Isolated Nucleoli}

Transcriptional activity was assayed according to previously reported methods ${ }^{10,11,12)}$. The assay buffer contained: $50 \mathrm{~mm}$ Tris- $\mathrm{HCl}, \mathrm{pH} 7.9,0.1 \mathrm{~m} \mathrm{KCl}, 2 \mathrm{~mm}$ dithiothreitol, $0.05 \mathrm{~mm}$ PMSF, $5 \mathrm{~mm} \mathrm{KF}$, $5 \mathrm{mM} \mathrm{MgCl}_{2}, 1 \mathrm{~mm}$ ATP, $1 \mathrm{~mm}$ GTP, $1 \mathrm{~mm} \mathrm{CTP}, 0.2 \mathrm{~mm}$ UTP, $5.0 \mu \mathrm{Ci} / \mathrm{ml}{ }^{3} \mathrm{H}-\mathrm{UTP}$, plus varying concentrations of anthracyclines. The final assay volume was $0.10 \mathrm{ml}$, and reactions were initiated by the addition of $0.01 \sim 0.02 \mathrm{ml}$ of nucleoli (approximately $55 \mu \mathrm{g}$ DNA). Reactions were run at $30^{\circ} \mathrm{C}$ for 30 minutes and $0.05 \mathrm{ml}$ aliquots were processed as previously reported ${ }^{12)}$. Results were displayed as percent inhibition versus log of drug concentration, and subjected to probit analysis as previously described $^{5,8,15)}$. Best fit lines were constructed and the $\mathrm{IC}_{50}$ values estimated as previously reported ${ }^{5,8}$.

\section{Acknowledgments}

The authors are indebted to Ms. Linda Whiteman, Ms. Polly Wischmeier and Ms. Julie Durantini for assistance in the preparation of this manuscript. We also thank Mr. C. MIRABELLI for assistance in the preparation and isolation of nucleoli, and Ms. R. K. Busch for transplanation of tumor cells. We are also indebted to Dr. N. R. BALlal for technical advise and helpful discussions regarding the interpretation of data. The support and guidance of Dr. HARris Busch are most appreciated. The authors also wish to thank Drs. A. Prestayko, C. H. Huang, as well as C. Mirabelli, S. Mong and L. Galvan for reviewing this manuscript.

\section{References}

1) Nitta, K.; S. Mizuno \& H. Umezawa: Biochemical method of screening of microbial products exhibiting antitumor activity. J. Antibiotics, Ser. A 19: 282 284, 1966

2) Nakamura, S.; T. Yajima, M. Hamada, T. Nishimura, M. Ishizuka, T. TAKeuchi, N. Tanaka \& H. UmeZAWA: A new antitumor antibiotic, phenomycin. J. Antibiotics, Ser. A 20: 210 216, 1967

3) Sakano, K-I.; T. Mizui, K. Akagi, M. Watanabe, H. Kondo \& S. Nakamura: On RnA-polymerases of leukemia L 1210 origin and an enzymatic method to screen antitumor antibiotics. J. Antibiotics 30: 500 505, 1977

4) Henry, D. W.; Adriamycin. in Cancer Chemotherapy (SArtorelli, A. C., ed.), 15-57, 169th meeting Amer. Chem. Soc. Div. Med. Chem. Symp., Philadelphia, PA, 1975

5) Crooke, S. T.; V. H. DuVernay, L. Galvan \& A. W. Prestayko: Structure activity relationships of anthracyclines relative to effects on macromolecular synthesis. Molecular Pharmacol. 14: 290 298, 1978 
6) DuVernay, V. H.; J. A. Pachter \& S. T. Crooke: Molecular pharmacological differences between carminomycin and its analog, carminomycin-11-methylether, and adriamycin. Cancer Res. 40: 387 394, 1980

7) Yamaki, H.; H. Suzuki, T. Nishimura \& N. Tanaka: Mechanism of action of aclacinomcyin A. I. The effect on macromolecular syntheses. J. Antibiotics 31: 1149 1154, 1978

8) Misumi, M.; H. Yamaki, T. Akiyama \& N. TAnaka: Mechanism of action of aclacinomycin A. II. The interaction with DNA and with tubulin. J. Antibiotics 32: 48 52, 1979

9) DuVernay, V. H.; J. M. Essery, T. W. Doyle, W. T. Bradner \& S. T. Crooke: The antitumor effects of anthracyclines: The importance of the carbomethoxy-group at position-10 of marcellomycin and rudolfomycin. Molecular Pharmcol. 15: $341 \sim 356,1979$

10) Ballal, N. R.; Y. C. Chot, R. Mouche \& H. Busch: Fidelity of synthesis of pre-ribosomal RNA in isolated nucleoli and nucleolar chromatin. Proc. Natl. Acad. Sci., U.S.A. 74: 2446 2450, 1977

11) Grummt, I.: Synthesis of RNA molecules larger than 45 s by isolated rat-liver nucleoli. Eur. J. Biochem. 57: $159 \sim 167,1975$

12) Blatti, S. P.; G. J. Ingles, T. J. Lindell, P. W. Morris, R. F. Weaver, F. Weinberg \& W. J. Rutter: Structure and regulatory properties of eucaryotic RNA polymerase. Cold Spring Harbor Symp. Quant. Biol. 35: 649 657, 1970

13) Weinmann, R. M. \& R. G. Roeder: Role of DNA-dependent RNA polymerase III in the trascription of the tRNA and 5S RNA genes. Proc. Natl. Acad. Sci., U.S.A. 71: 1790 1794, 1974

14) Roeder, R. G. \& W. J. Rutter: Specific nucleolar and nucleoplasmic RNA polymerases. Proc. Natl Acad. Sci., U.S.A. $65: 675 \sim 682,1970$

15) Litchfield, J. T., Jr. \& F. Wilcoxon: A simplified method of evaluating dose-effect experiments. J. Pharm. \& Expt. Therapeut. 96: 99 113, 1949

16) Grummt, I.: In vitro synthesis of pre-rRNA in isolated nucleoli. In The Cell Nucleus (Busch, H., ed.), Vol. 5, pp. 373 414, Academic Press, Inc., New York, 1978 